\title{
Pre- and Post- Conviction DNA Collection Laws in the United \\ States: An Analysis of Proposed \\ Model Statutes
}

Journal of Criminal Justice and Law Volume 1, Issue 1, pp. 22-41 (C) University of Houston-Downtown

\author{
Xiaochen Hu ', Mai E. Naito², Rolando V. del Carmen ${ }^{3}$
}

\begin{abstract}
DNA is one of the most powerful molecular tools being widely used in criminal investigations today. Pre- and post-conviction DNA collection laws govern when DNA must be collected, where it is stored, and who has access to the information. Currently, all fifty states have post-conviction DNA collection laws, but only thirty states have enacted pre-conviction DNA collection laws. Details of the procedures and requirements in state statutes vary by state. This study analyzes the current statutes to identify strengths and weaknesses and propose a model statute to standardize DNA collection laws nationwide. By using Herbert Packer's two models for criminal justice processes as a theoretical framework, the proposed pre-conviction and post-conviction DNA laws offer a foundation for states that may consider revising or adopting DNA collection laws.
\end{abstract}

\section{Keywords}

DNA, statutes, pre- and post-conviction

\section{Introduction and Background}

Alonzo Jay King was arrested by Maryland police in 2009 and charged with first- and second-degree assault. ${ }^{1}$ While in custody at the Wicomico County Central Booking facility, a DNA sample was

\footnotetext{
${ }^{1}$ Maryland v. King, 133 S. Ct. 1958 (2013).
}

\footnotetext{
' Department of Criminal Justice, Fayetteville State University, Fayetteville, NC, USA

${ }^{2}$ Department of Criminology, University of West Georgia, Carrollton, GA, USA

${ }^{3}$ College of Criminal Justice and Criminology, Sam Houston State University, Huntsville, TX, USA

Corresponding Author:

Mai E. Naito, Department of Criminology, University of West Georgia, Carrollton, GA, 30118, USA

Email: mnaito@westga.edu
}

Acknowledgement: We would like to thank the National Conference of State Legislatures (NCSL) and Susan Strickland from the Newton Gresham Library in Sam Houston State University for providing help with searching related state statutes. 
taken from King during the booking procedure under the Maryland DNA Collection Act. ${ }^{2}$ After being added to the Maryland DNA database, King's DNA matched a record of an unsolved rape case from 2003. ${ }^{3}$ King was then also charged and convicted with first-degree rape. ${ }^{4} \mathrm{He}$ appealed and argued that taking his DNA while being arrested violated his Fourth Amendment right against unreasonable search and seizure. ${ }^{5}$ The U.S. Supreme Court ruled in 2013 that taking DNA sample from persons who are arrested but not convicted is constitutional. ${ }^{6}$ This is the first time the Court has addressed the issue of whether taking DNA sample from an arrestee is constitutional.

The opinion in Maryland v. King was written by Justice Kennedy who was joined by Chief Justice Roberts and Justices Thomas, Breyer, and Alito. The majority opined that taking a DNA sample from an arrestee who is not convicted is constitutional. ${ }^{7}$ Three major reasons were discussed: First, it is believed that DNA testing will be accepted similar to the use of fingerprints. ${ }^{8}$ Second, the Maryland DNA Collection Act has strict rules on how law enforcement are authorized to collect, store, and analyze DNA samples. ${ }^{9}$ According to the majority's perspective, the rules adequately protect individuals' privacy, including innocent individuals. ${ }^{10} \mathrm{Third}$, as an identification tool, DNA identification technology can rapidly achieve two important goals of identification in the criminal justice procedure-identifying an individual and retrieving his or her criminal history. ${ }^{11}$ The dissenting opinion by Justice Scalia was joined by Justices Ginsburg, Sotomayor, and Kagan. The main concern from the dissent argued that identifying individuals does not equate to solving cold cases. ${ }^{12}$ If law enforcement agencies are using DNA information collected from an arrestee to link to an unsolved case, they are conducting a suspicion-less search, which is forbidden by the Fourth Amendment. ${ }^{13}$ Justice Scalia also pointed out that current DNA statutes do not provide enough rules for collecting and analyzing DNA samples. ${ }^{14}$ An innocent individual may have his or her DNA sample added into a database due to an arrest, even if it is an unlawful arrest. ${ }^{15}$

The use of DNA is one of the most powerful forms of forensic identification that has significantly altered police investigations and the law must be equipped with how such information can be used without violating privacy. ${ }^{16}$ The recent Supreme Court decision in King set precedent that has opened the doors for DNA to be collected prior to conviction and such information may be used against national databases without specific requirements on reducing errors.

To bring the issue on how the government can protect DNA evidence from being fraudulently accessed or abused, the current research analyzed pre- and post-conviction DNA collection laws.

${ }^{2}$ Id. at 1962.

${ }^{3}$ ld.

${ }^{4} / d$.

${ }^{5} / d$.

${ }^{6} / d$. at 1966.

${ }^{7}$ Id.

${ }^{8} / d$.

${ }^{9} / d$.

$10 / d$.

${ }^{11} / d$.

$12 / d$.

${ }^{13} / d$.

${ }^{14} / d$.

${ }^{15} / d$.

${ }^{16}$ Stephanie L. Albertson, Effect of Jurors' Race on Their Response to Scientific Evidence (2012). 
While all 50 states have post-conviction DNA collection laws that generally require individuals to surrender DNA after conviction, only thirty states have pre-conviction DNA collection laws as of May 2015. The King case decided that collecting DNA before an individual is convicted is constitutionally permissible; however, not all states have pre-conviction DNA collection laws. This suggests that reservations exist in some states about collecting DNA samples. Some state laws are well-written with details on the procedure to be followed, but other statutes can benefit from better provisions. Also, this study applies Herbert Packer's two models to discuss how proposed DNA collection laws can be implemented to achieve a balance between the crime control and due process models. In sum, this paper identifies and analyzes existing state statutes and proposes model statutes for both pre- and post-conviction DNA collection laws to promote standardization in how DNA is collected, stored, and analyzed across the states.

\section{A. DNA and DNA Identification Technology}

DNA technology has played a significant role in numerous cases in criminal investigations. ${ }^{17}$ DNA has also resulted in over 300 exonerations. ${ }^{18}$ Cronan gives two reasons why there is a "universal adoration of DNA in forensic science." ${ }^{19}$ The first is that genetic instruction encoded in DNA is unique to all living organisms and capable of being used for identification. ${ }^{20}$ The second reason is that DNA molecules are highly stable. ${ }^{21}$ Unlike fingerprints, which could be easily tainted before collection at the crime scene, DNA evidence is more reliable and precise.

The deoxyribonucleic acid (DNA) molecule can be found in all living cells such as blood cells, hair roots cells, and sperm. ${ }^{22}$ While it is commonly believed that DNA can provide accurate identification, misidentification is possible if one is not knowledgeable about the types of DNA. ${ }^{23}$ The variations, which determine a person's DNA to be unique, are located in "a multitude of genomic sites." 24 Polymorphic genes account for these variations, which allow scientists to create an individual-specific DNA profile. ${ }^{25}$ There are two types of DNA-Nuclear DNA (nDNA) and Mitochondrial DNA (mtDNA). Nuclear DNA, found in the nucleus of a cell, is unique to each person because it is inherited from both parents. ${ }^{26}$ Mitochondrial DNA, found in the mitochondria, is less powerful than the nDNA because it is inherited only from the mother, which may result in multiple hits if an individual has siblings from the same mother. ${ }^{27}$ While nDNA is more reliable, mtDNA is more stable and can be found in multiple locations within a cell. ${ }^{28}$ This distinction is important because DNA analysis is different depending on the type of DNA.

17 John P. Cronan, The Next Frontier of Law Enforcement: A Proposal for Complete Databanks, 28 AM. J. CRIM. L. 119, 121 (2000).

${ }_{18}$ INNOCENCE PROJECT, http://www.innocenceproject.org (last visited Feb. 22, 2016).

${ }^{19}$ Cronan, supra note 17 , at 124 .

${ }^{20} / d$.

21 Id.

$22 / d$. at 121.

$23 / d$.

24 Id.

$25 / d$.

${ }^{26}$ Mal E. Naito, \& Michael S. VAughn, DNA Evidence and Wrongful Convictions, in The Encyclopedia of CRIMINology ANd CRIMINAL Justice (Hemmens, 2 d ed. 2015).

27 Id.

${ }^{28} / d$. 
Forensic DNA testing is different from complete individual-specific DNA profiling. In forensic DNA testing, scientists focus on repeated DNA sequences known as short tandem repeats (STRs). STRs resemble an accordian and contain repetitive sections of the DNA sequence that can be processed quickly. Alleles are variants of a gene that contain minor differences of the same basic genetic information. Thirteen locations of STR alleles are used to compare and identify a person. ${ }^{29}$ In DNA databases, only the thirteen locations of STR alleles known as "fragment or DNA" are stored in the DNA profile. ${ }^{30}$ Most state and federal crime laboratories also store the whole DNA sample. Both the DNA profile and sample contain personal information that are under the control of the government. The challenge is how to secure such personal information without infringing on an individual's rights.

\section{B. Theoretical Framework: Packer's Crime Control and Due Process Models}

In 1964, Herbert Packer proposed two models of the criminal process: crime control model and due process model. ${ }^{31}$ His primary purpose of creating the two models was to examine how laws were implemented in the criminal process. ${ }^{32}$ In his paper, Packer also stated that the two models should not be labelled as good or bad; instead, the two models were merely used to explain the operation of criminal process. ${ }^{33}$ This philosophy applies to the current study because the purpose is to propose possible statutes that could balance both models in the process of collecting a DNA sample.

The crime control model emphasizes the repression of criminal behavior and treats it as the most important function of the criminal process. ${ }^{34}$ To successfully operate the crime control model, the criminal justice system must have a high rate of apprehension and conviction. ${ }^{35}$ In this study, that would mean the criminal justice system must obtain as many DNA samples as possible. These DNA samples are collected from the arrestees and the convicted to maximize the probability of solving criminal cases. Without further limitation, it is imaginable that in the future, the crime control model requires everyone in society to provide his or her DNA sample in order to prepare for a potential or forthcoming criminal behavior.

The due process model emphasizes the reliability of the fact-finding process. ${ }^{36}$ According to Packer, the due process model did not ignore the importance of repressing criminal behavior, but it rejected the informal fact-finding process. ${ }^{37}$ The purpose of due process model is to maximize fairness in the criminal process. Although the DNA profile only has thirteen locations of STR alleles stored, $^{38}$ the DNA database has been criticized about the ease of having an individual's DNA information saved, but difficult to get it expunged. ${ }^{39}$ To prevent the abuse of DNA samples and

\footnotetext{
${ }^{29}$ See Maryland v. King, 133 S. Ct. 1958 (2013) at majority.

${ }^{30} \mathrm{Id}$.

${ }^{31}$ Herbert L. Packer, Two Models of the Criminal Process, 113 U. PenN. L. Rev. 1 (1964).

32 Id. at 5.

33 Id. at 6 .

${ }^{34}$ Id. at 9 .

${ }^{35} / d$. at 10.

${ }^{36} / d$. at 14.

${ }^{37}$ Id.

${ }^{38}$ See King, 133 S. Ct. 1958 (2013) at majority.

${ }^{39}$ Stephanie Beaugh, Comment, How The DNA Act Violates The Fourth Amendment Right to Privacy of Mere Arrestees and Pre-trial Detainees, 59 LoY. L. Rev. 157 (2013).
} 
profiles at its root, collecting DNA samples appears to be the gatekeeper. It may be suitable to only collect DNA samples from arrestees of serious crimes, but they must be guaranteed the right to expunge if they are innocent.

To achieve a balance between the crime control and due process models in relation to DNA collection laws, it is imperative for the procedures to be consistent on how it is collected, stored, and analyzed. While it is important for law enforcement to use DNA to solve cases, it is also important to respect an individual's rights on whether the government should have such sensitive information at its disposal. These two models will be used throughout the analysis of DNA collection laws.

\section{DNA Collection Laws}

Prior to 2000, scholars disagreed on the purpose for obtaining DNA or the need for various forensic technology. ${ }^{40}$ They were unsure about DNA collection and worried about Fourth Amendment violations. In 2000, Congress passed the DNA Analysis Backlog Elimination Act also known as the DNA Act. ${ }^{41}$ It requires law enforcement officers to obtain a DNA sample from a person "in [the] custody of the Bureau of Prisons who is, or has been, convicted of a qualifying federal offense," 42 as well as a person who is "on release, parole, or probation." 43

Anticipating constitutional challenges, Congress embedded provisions in the DNA Act to protect individual's rights. ${ }^{44}$ For example, the Act has limitations on who has access to the DNA database, and how DNA samples are used. ${ }^{45}$ The Combined DNA Index System (CODIS) is a computer software program operated by the FBI to run DNA databases. The National DNA Index System (NDIS) is part of CODIS on a national level that contains DNA profiles from participating federal, state, and local forensic laboratories. ${ }^{46}$ The DNA Act has procedures on expunging DNA samples from CODIS; however, it does not truly protect individuals from further constitutional attacks. ${ }^{47}$ Some scholars argue that once a person's DNA sample is entered into CODIS, there is no way to know whether the actual DNA sample can be expunged because "there is no process or provision to compel its destruction," 48 even if the individual is found wrongfully convicted. Moreover, financial considerations make DNA collection and analysis more problematic. Athens and Rower analyzed Alaska's DNA collection statutes, and argued that "the collection, processing, and storage of DNA is a costly business." ${ }^{49}$ DNA collection and analysis costs more than fingerprinting. The Innocence Project indicated that the average cost of DNA collection and

\footnotetext{
40 Megan Pownall, Case Comment, Twenty-First Century Fingerprints: The Third Circuit's Approval of DNA Collection Upon Arrest in United States v. Mitchell, 57 VILL. L. ReV. 763, 764 (2012).

4142 U.S.C. § 14135 (2014).

42 Id.

${ }^{43} / d$.

${ }^{44}$ Pownall, supra note 40 , at 765.

4542 U.S.C. § 14135.

${ }^{46}$ Federal Bureau of Investigation Laboratory Services, https://www.fbi.gov/about-us/lab/biometricanalysis/codis/codis-and-ndis-fact-sheet (last visited Dec. 12, 2016).

47 Pownall, supra note 40 , at 765.

${ }^{48}$ Beaugh, supra note 39, at 158.

${ }^{49}$ Marika R. Athens \& Alyssa A. Rower, Alaska's DNA Database: The Statutes, Its Problems, and Proposed Solutions, 20 AlaSKa L. ReV. 389, 390 (2003).
} 
analysis is $\$ 1,000$ per test..$^{50}$ Some states have ruled that the DNA provider must pay for the costs of DNA collection and analysis. ${ }^{51}$

State legislatures are cautious about passing pre-conviction as opposed to post-conviction DNA statutes. Currently, only thirty states have pre-conviction DNA collection statutes, which allow law enforcement officers to obtain a DNA sample from an arrestee rather than from an individual who has been convicted. Pre-conviction DNA collection statutes have generated more attention because an arrestee has not been adjudicated, and some arrestees may not have met with an attorney or appeared before a judge before they must relinquish their DNA. Using the arrestee's DNA sample as an identification tool for the crime in which he or she was arrested does not make sense because probable cause must have been established for the individual to be arrested to begin with. Moreover, linking an arrestee to other unsolved cases violates the due process model. The Due Process Model suggests that a person should be innocent until found guilty. ${ }^{52}$ Justice Scalia warned in his dissenting opinion in King that identifying an individual that is not the crime for which he or she was originally arrested for is considered a suspicion-less search, which is forbidden by the Fourth Amendment. ${ }^{53}$

The Court's decision in King did not end the debate over collecting DNA samples before conviction. In State v. Emerson, ${ }^{54}$ the Supreme Court of Ohio ruled that no person has a reasonable expectation of privacy in his or her DNA profile. ${ }^{55}$ Heil argued that the Supreme Court of Ohio's decision "opens the door for potentially unlimited uses of DNA sampling." ${ }^{56}$ Some scholars argue that DNA collection should be judged based on two tests which are: "totality of the circumstances" and "special needs." 57 The totality of the circumstances test applies to determine whether an offender has a lower expectation of privacy. ${ }^{58}$ The special needs doctrine test is used to determine whether the warrant or probable cause is impractical. ${ }^{59}$ However, even under these tests, courts have reached different outcomes. ${ }^{60}$ In United States v. Mitchell, ${ }^{61}$ the Third Circuit Court of Appeals held that the federal pre-conviction DNA statutes are constitutional. ${ }^{62}$ In contrast, the California Courts of Appeal held in People v. Buza ${ }^{63}$ that California's pre-conviction DNA statute violated the Fourth Amendment when there was no judicial probable cause on the arrestee; however this

\footnotetext{
${ }^{50}$ INNOCENCE PROJECT, http://www.innocenceproject.org/faqs/how-much-does-dna-testing-cost (last visited Apr. 30, 2015).

51 Or. Rev. Stat. § 137.076 (2014); OKLA. Stat. tit. 74 § 150.27a (2016); Neb. ReV. Stat. § 29-4106 (2012); IdAhO

CODE § 19-5506 (2014).

52 Packer, supra note 31.

53 Maryland v. King, 133 S. Ct. 1958 (2013).

${ }^{54}$ State v. Emerson, 981 N.E.2d 787, 789 (2012).

${ }^{55} / d$.

${ }^{56}$ Brendan Heil, Striking a Balance: Why Ohio's Felony-Arrestee DNA Statute Is Unconstitutional and Ripe for Legislative Revision, 61 CLEV. St. L. REV. 529, 539 (2013).

57 Id. at 4. See also Ashley Eiler, Arrested Development: Reforming the Federal All-Arrestee DNA Collection Statutes to comply with the Fourth Amendment, 79 GEO. WASH. L. REV. 1201, 1205 (2011).

${ }^{58}$ Heil, supra note 56 , at 539.

59 Id. at 533.

$60 / d$.

61 United States v. Mitchell, 652 F.3d 387 (2011).

62 Id.

63 People v. Buza, 129 Cal. Rptr.3d 753 (2011).
} 
decision was abrogated. ${ }^{64}$ Some states' pre-conviction DNA collection statutes rule that there should be probable cause for law enforcement officers to collect DNA samples from an arrestee, ${ }^{65}$ otherwise, the arrestee can refuse to provide his or her DNA sample. ${ }^{66}$

Researchers have predictably criticized the Supreme Court's decision in King. Noronha argued that the Court sacrifices "the Fourth Amendment to build up the DNA database" and concludes that the Court's decision "leaves room for government abuse." ${ }^{67}$ Moreover, Joh stated that the majority opinion in King is insufficient and the Court's decision has reduced our genetic privacy. ${ }^{68}$ Other scholars maintain that certain limitations and requirements should be established before collecting DNA samples from arrestees. Lapp and Radice stated that probable cause established by a neutral third-party can balance the interests of the government and individual privacy, thus, reducing the chance for abuse. ${ }^{69}$ Some researchers, however, support expanding the DNA database because having such information could help lower the crime rate. ${ }^{70}$

\section{Federal Laws on Pre- and Post- Conviction DNA Collection}

This study analyzes the current state statutes and proposes model statutes to standardize DNA laws across the states. Background knowledge of federal laws on pre- and post- conviction DNA collection is necessary to help understand state legislation. The DNA Identification Act of 1994 passed by Congress authorized the FBI to establish CODIS, and the DNA Backlog Elimination Act of 2000 allowed the Federal DNA Database Unit to collect DNA samples from federal convicted offenders. ${ }^{71}$ In 2006, Congress passed the DNA Fingerprint Act of 2005, which required federal arrestees to provide their DNA samples. ${ }^{72}$ The federal DNA law contains copious details; ${ }^{73}$ however, very few states have used them. The controversy surrounding the constitutionality of both pre-conviction and post-conviction DNA collection statutes requires that collecting DNA samples must be well-designed, even under the state DNA collection statutes. It is the goal of this paper to attempt a balance between crime control and due process models ${ }^{74}$ in both pre- and post- conviction DNA collection laws. The following section analyzes current pre-conviction DNA laws in thirty states.

\footnotetext{
64 Id.

${ }^{65}$ Va. Code AnN. § 19.2-310.2:1; Vt. Stat. AnN. tit. 20 § 1933 (2016); N.M. Stat. AnN. § 29-3-10 (2011); MinN. STAT.§ 299C.105 (2006).

${ }^{66}$ N.C. Gen. StAT. § 15A-266.3A (2015).

${ }^{67}$ Stephanie B. Noronha, Comment, Maryland v. King: Sacrificing the Fourth Amendment to Build Up the DNA Database, 73 MD. L. Rev. 667 (2014).

${ }^{68}$ Elizabeth E. Joh, Maryland v. King: Policing and Genetic Privacy. 11 OHIO ST. J. CRIM. L. 281 (2013).

${ }^{69}$ Kevin Lapp \& Joy Radice, A Better Balancing: Reconsidering Pre-Conviction DNA Extraction from Federal Arrestees, 90 N.C. L. ReV. 157A (2012).

70 Rana Santos, Why DNA Databasing Is Good for Maryland: A DNA Analyst's Perspective, 42 U. BALT. L. REV. 591 (2013).

${ }^{71}$ Federal Bureau of InVestigation, Legislation Affecting the Federal DNA Database Unit, http://www.fbi.gov/about-us/lab/biometric-analysis/federal-dna-database/legislation-affecting-thefederal-dna-database-unit (last visited June 1, 2015).

72 Id.

7342 U.S.C. § 14132 (1994); § 14135(a); § 14137.

${ }^{74}$ Packer, supra note 31.
} 


\section{State Pre-Conviction DNA Collection Statutes}

As of May 2015, only thirty states had pre-conviction DNA collection laws. Table 1 summarizes the variables that have been analyzed in the current paper. These variables, which are summarized from state statutes, particularly reflect Justice Scalia's concerns in King such as crime type, DNA collection and storage, and expungement process. ${ }^{75}$

\section{A. Crime Type Required for DNA Sample}

State statutes limit the collection of DNA samples to persons who have committed certain crimes. Among the thirty states that have pre-conviction DNA collection statutes, twenty-nine states have the same crime types in both pre-conviction and post-conviction statutes. Only in Maryland are the pre-conviction DNA collection statute and the post-conviction DNA collection statutes different. ${ }^{76}$ In Maryland, arrestees who are charged with a violent crime or burglary must

${ }^{75}$ Maryland v. King, 133 S. Ct. 1958 (2013).

76 Md. Pub. Safety Code AnN. § 2-504 (West 2009). 
provide DNA samples. ${ }^{77}$ Most state statutes include felonies, but specifically mention sex offenses, ${ }^{78}$ adjudicated delinquent, ${ }^{79}$ burglary, ${ }^{80}$ and kidnapping. ${ }^{81}$ Rather than looking at the offense, the statute in South Carolina decided that an offense that is punishable by a prison sentence of five years or more must provide a DNA sample. ${ }^{82}$ Since DNA collection and analysis is expensive and many crime laboratories are overburdened with cases, it is suggested to limit DNA evidence collection to serious crimes.

\section{B. When to Provide DNA Sample}

Most states (twenty-one out of thirty) require that after a person has been arrested, his or her DNA sample must be collected. ${ }^{83}$ Other statutes (such as New Mexico and Vermont) provide that the presence of probable cause suffices to collect DNA. ${ }^{84}$ Although law enforcement must have probable cause when making an arrest, ${ }^{85}$ it is also an important component in pre-conviction DNA collection laws because probable cause alone does not always lead to an arrest. Instead, it can result in a person being "summoned to appear before a magistrate for the commission of a felony." ${ }^{86}$ Some states require that probable cause must be confirmed by "a magistrate or a grand jury" before an arrestee's DNA is collected. ${ }^{87}$ Other states (such as Colorado, Florida, Missouri, New Mexico, North Dakota, South Dakota, and Utah) require that DNA must be collected during the booking procedure, ${ }^{88}$ sometimes together with fingerprinting. ${ }^{89}$ Texas's pre-conviction DNA statute requires law enforcement to collect a DNA sample from an arrestee "immediately after fingerprinting the defendant and at the same location as the fingerprinting occurs." ${ }^{\prime 90}$

77 Id.

78 Ala. Code § 36-18-25 (2016); Ala. Code § 36-18-24 (2016); Alaska Stat. § 44.41 .035 (West 2010); Mich. Comp. Laws Serv. § 750.520m (LexisNexis 2015); Minn. Stat. § 299C.105 (2006); MinN. STAT. § 299 C. 11 (2013); Mo. Rev. Stat. § 650.055 (2012) .; N.D. Cent. Code § 31-13-03 (2011); N.J. Rev. Stat. § 53:1-20.20, 20.25 (2013); TENN. CODE ANN. § 40-35-321 (2012).

${ }^{79}$ ARIZ. ReV. StAt. § 13-610 (LexisNexis 2016).

80 Md. Pub. Safety Code AnN. § 2-504; Mo. Rev. Stat. § 650.055.

81 See N.J. Rev. StAT. § 53:1-20.20; N.C. Gen. StAT. § 15A-266.3A (2015).

82 S.C. CODE ANN. § 23-3-620 (2009).

83 Cal. Penal Code $\S 296$ (Deering 2004); Ala. Code § 36-18-24 (2016); Ark. Code Ann. § 12-12-1006 (2015); Fla. Stat. § 943.325 (2016); Kan. Stat. Ann. § 21-2511 (2014); La. Stat. Ann. 15:609 (2010); Mich. Comp. Laws Serv. $\S 750.520 m$ (LexisNexis 2015); N.J. Rev. StAT. § 53:1-20.20 (2013); N.M. StAT. ANN. § 29-3-10 (2011); N.C. Gen. Stat. § 15A-266.3A (2015); Ohio Rev. Code Ann. 2901.07 (West 2012); S.C. Code AnN. §23-3-620 (2009); S.D.

Codified LAWs § 23-5A-5.2 (2016); Tex. Gov't Code Ann. § 411.1471 (2015).

84 N.M. Stat. ANn. § 29-3-10 (2011); Vt. Stat. AnN. tit. 20 § 1933 (2016).

85 Rolando V. del Carmen, Criminal Procedure: Law and Practice 84 (Wadsworth, 9th ed. 2013).

${ }^{86}$ N.D. CENT. CODE $\S 31-13-03$ (2011).

87 VA. Code Ann. § 19.2-310.2:1 (2006); Vt. Stat. Ann. tit. 20 § 1933 (2016).

88 Colo. Rev. Stat. § 16-23-103 (2010); Fla. Stat. § 943.325 (2016); Mo. ReV. Stat. § 650.055 (2012); N.M. Stat. ANN. § 29-3-10 (2011); N.D. CENT. CODE § 31-13-03 (2011); S.D. CodIFIEd LAWs § 23-5A-5.2 (2016).

89 N.C. Gen. StAT. § 15A-266.3A (2015); Tex. Gov’t Code AnN.§ 411.1471 (2015).

90 Tex. Gov't Code AnN § 411.1471 (2015). 


\section{DNA Collection in Juvenile Cases}

Although many statutes (nineteen out of thirty) do not explicitly contain provisions on whether pre-conviction DNA collection statutes apply to juveniles, some states (11 out of 30) rule that juvenile arrestees should also have their DNA samples collected. States such as Alaska and Missouri require the suspect to be at least sixteen-,${ }^{91}$ seventeen-,${ }^{92}$ or eighteen-years-old. ${ }^{93} \mathrm{New}$ Jersey's statute states that juveniles "arrested for an act which, if committed by an adult, would constitute an offense" must provide a DNA sample. ${ }^{94}$ Other statutes allow pre-conviction DNA collection to be applied to both adults and juveniles. Wisconsin requires that a person must provide DNA sample if he or she "was arrested, or the juvenile was taken into custody, under a warrant." ${ }^{95}$ Among states with pre-conviction DNA collection laws for juveniles, there is no difference between adults and juveniles' provisions on crime types. ${ }^{96}$

\section{Where DNA Samples are Stored and Expungement Process}

Usually, both pre- and post-conviction DNA samples are stored at the same location. If a statewide crime laboratory is in charge of convicted offenders' DNA analysis and storage, it is also responsible for arrestees' DNA. In some states, however, pre-conviction DNA samples are stored in the same jurisdiction where it was collected, such as in its local crime laboratory.${ }^{97}$ The rationale for this storage in the local crime laboratory is that it is more difficult to expunge DNA samples and profiles if they are entered into a state or national database. ${ }^{98}$

The expungement process in pre-conviction DNA collection laws is usually more detailed because arrestees have not been adjudicated. Among the thirty states with pre-conviction DNA laws, seventeen states have a clear section on the expungement process. Some states (such as Alabama, Alaska, Colorado, Maryland, Nevada, New Jersey, Tennessee, and Texas) indicate that the DNA sample must be destroyed only if the charge is dismissed or the person has been acquitted

${ }^{91}$ AlASKA StAT. § 44.41 .035 (West 2010).

92 Mo. Rev. Stat. $\S 650.055$ (2012).

93 N.D. Cent. Code § 31-13-03; Ohı Rev. Code Ann.2901.07 (West 2012); S.D. Codified LaWs § 23-5A-5.2.

${ }^{94}$ N.J. REV. STAT§ 53:1-20.20 (2013).

95 WIS. STAT. $§ 165.84$ (2016).

${ }^{96}$ Ala. Code § 36-18-25 (2016); Ala. Code § 36-18-24 (2016); Alaska Stat. § 44.41 .035 (West 2010); Ariz. Rev. Stat. § 13-610 (LexisNexis 2016); Fla. Stat. § 943.325 (2016); Kan. Stat. AnN. § 21-2511 (2014); La. Stat. AnN. 15:609 (2010); Minn. Stat. § 299C.105 (2006); Minn. Stat. §299C.11 (2013); Mo. ReV. STAT. § 650.055 (2012); N.J. Rev. StAT.§53:1-20.20, 20.25 (2013); UtAH Code ANN. § 53-10-403 (West 2015); WIS. StAT. § 165.76, 165.84 (2015).

${ }^{97}$ Ark. Code Ann. § 12-12-1006 (2015); Md. Pub. Safety Code Ann. § 2-504 (West 2009); Mo. Rev. Stat. § 650.055 (2012); N.M. Stat. Ann. § 29-3-10 (2011); N.C. Gen. Stat. § 15A-266.3A (2015); N.D. Cent. Code § 3113-03 (2011); TEX. Gov'T CODE ANN. § 411.1471 (2015).

${ }^{98}$ Beaugh, supra note 39 . Beaugh argued that it is hard to know whether the actual DNA sample is expunged if it enters into CODIS. Id. 
of the charge. ${ }^{99}$ Other states (such as Arizona, Pennsylvania, Florida, Illinois, and Kansas) require both DNA sample and profile in the database to be expunged. ${ }^{100}$

\section{E. Other Provisions Worth Noting in Pre-Conviction DNA Laws}

Alabama's pre-conviction DNA collection statute states that "any person...shall consent in writing freely and voluntarily to provide a DNA sample" and that the individual has "the right to refuse to provide a sample without penalty" and "refusal may not be used as evidence against the person in any proceeding." 101 To achieve balance with the due process model, allowing arrestees to provide DNA sample voluntarily is reasonable because the DNA sample is only used for identification purposes. If a law enforcement agency has the person in custody, photographs and fingerprints suffice for identification. However, if the arrestee is accused of a serious crime (e.g., homicide and/or a sexual crime) and there are no other evidence for identification, use of reasonable force to obtain a DNA sample collection may be an option.

North Carolina's pre-conviction DNA collection statute states that "if the person is arrested without a warrant, the DNA sample must not be taken until a probable cause determination has been made." 102 This is a notable aspect of this statute because some scholars are skeptical about the expungement process. ${ }^{103}$ Texas's pre-conviction DNA collection statute treats arrestees differently based on the crime committed. ${ }^{104}$ Individuals arrested for a serious offense must give their DNA sample immediately after arrest, ${ }^{105}$ while others can provide their DNA sample voluntarily at any time. ${ }^{106}$ This indicates that collecting DNA for serious crimes is a priority in that jurisdiction. There are differences among statutes as to what can be done when arrestees refuse to cooperate if asked to submit DNA. ${ }^{107}$ Some states mandate that law enforcement use reasonable force to collect DNA samples, ${ }^{108}$ while others require a court order. ${ }^{109}$

\footnotetext{
${ }^{99}$ Ala. Code§ 36-18-25 (2016); Ala. Code §36-18-24 (2016); Alaska Stat. § 44.41 .035 (West 2010); Colo. Rev. Stat. 16-23-103 (2010); Md. Pub. Safety Code Ann. § 2-504 (West 2009); Nev. Rev. Stat. Ann. § 176.09123 (West 2013); N.J. Rev. Stat.§ 53:1-20.20, 20.25 (2013); Tenn. Code AnN. § 40-35-321 (2012); TeX. Gov’t Code ANN. § 411.1471.

100 ARIz. Rev. Stat. § 13-610 (LexisNexis 2016); Cal. Penal Code § 296, § 296.1, § 299 (2004); Fla. Stat.§ 943.325 (2016); 730 Ill. Comp. Stat. Ann. 5/5-4-3 (West 2014); Kan. Stat. AnN. § 21.2511 (2014); Minn. Stat. § 299C.105 (2006); Minn. Stat. § 299C.11 (2013); Mo. Rev. Stat. § 650.055 (2012); N.C. Gen. Stat. § 15A-266.3A (2015); VA. CODE ANN. § 19.2-310.2:1 (2006).

${ }^{101}$ ALA. CODE $\S 36-18-25$.

102 N.C. Gen. STAT. § 15A-266.3A.

103 Beaugh, supra note 39, at 158.

104 TEX. Gov'T CODE ANN. § 411.1471 (2015).

105 Id.

$106 / d$.

107 E.g., Haskell v. Harris, 745 F.3d 1269 (2014).

108 Alaska Stat. § 44.41 .035 (West 2010); ARk. Code AnN. § 12-12-1006 (2015); N.H. Rev. Stat. AnN. § 651-C:2 (2010).

109 W. VA. CODE § 15-2B-6 (2011).
} 


\section{State Post-Conviction DNA Collection Statutes}

All fifty states have detailed statutes on post-conviction DNA collection. Table 2 identifies the variables that are analyzed in this paper.

\section{A. Crime Type Required for DNA Sample}

State statutes require offenders to provide a DNA sample if they are convicted of violent crimes, such as murder and/or rape. ${ }^{110}$ In property crimes, first-degree burglary is usually included as a crime type. ${ }^{111}$ Many states require sex offenders to provide samples. Missouri requires persons who are registered as sex offenders to provide a DNA sample before release. ${ }^{112}$ Some states do not have clear statements on crime types in their DNA collection statutes. Instead, they refer to other state statutes to define crime types (e.g., an individual is found guilty of a felony or

110 ALASKA StAT.. $§ 44.41 .035$ (West 2010).

111 Mo. REV. STAT. § 650.055 (2012).

112 Id. 
any offense under their state code). ${ }^{113}$ Some DNA collection statutes include crime types that require obtaining a DNA sample. Utah has a detailed crime type list, and identifies crimes such as "sale or use of body parts" and "failure to stop at an accident that resulted in death." 114 Among the fifty states, New Jersey is the only state that lists different types of sex offenses, such as aggravated sexual assault and aggravated criminal sexual contact. ${ }^{115}$

For juveniles, some states, such as Arizona, use the term "adjudicated delinquency" to identify offenses committed by juveniles that are a felony if committed by an adult. ${ }^{116}$ Juveniles who commit these crimes are required to provide a DNA sample. Many states (thirty-six out of fifty) do

$113 / d$.

114 UtAh Code AnN. § 53-10-403 (West 2015).

115 N.J. ReV. STAT.§ 53:1-20.20 (2013).

116 See Alaska Stat. § 44.41 .035 (West 2010); ARIz. Rev. Stat. § 13-610 (LexisNexis 2016); Iowa Code $§ 81.2$ (2014); Kan. Stat. Ann.§ 21-2511 (2014); La. Stat. AnN. 15:609 (2010); Minn. Stat. § 299C.105 (2006); N.J. ReV. Stat. § 53:1-20.20; S.C. Code ANn. § 23-3-620 (2009); WASH. Rev. Code § 43.43 .754 (2015). 
not have a clear section for juvenile offenders. However, Hawaii explicitly states that no juvenile is required to provide a DNA sample even if the act is considered a felony if committed by an adult. ${ }^{117}$ In sum, the post-conviction DNA laws for both adults and juveniles are similar.

\section{B. When to Provide DNA Sample}

Every state has post-conviction DNA laws where an offender must relinquish DNA upon conviction. However, some statutes require offenders to provide DNA after pleading guilty. ${ }^{118}$ Other states prescribe that even if an offender is found "not guilty by reason of insanity" or "guilty but mentally ill," ${ }^{119}$ a DNA sample is still obtained. ${ }^{120}$ An issue with when to submit DNA sample after conviction is whether it applies retroactively. Some statutes (twenty-four out of fifty) are retroactive in effect and specify a start date when the new law takes effect. For example, Alabama requires offenders convicted after May 6, 1994 to provide DNA samples, ${ }^{121}$ while Rhode Island requires persons who were convicted after June 29, 1998.122 Most dates vary by state. For instance, offenders in Indiana have to provide DNA sample if they committed offenses against the person or burglary after June 30, 1996, ${ }^{123}$ but all other crimes takes effect after June 30, 1998. ${ }^{124}$ Some statutes (thirteen out of fifty) also have sections about requiring persons on parole, probation, or any other forms of release to provide DNA samples as a part of the conditions on release. ${ }^{125}$

\section{Where DNA Samples Are Stored}

All DNA databases are index systems containing both the DNA sample and profile. DNA samples need a physical place, while DNA profiles are generally stored electronically. Some DNA databases are operated by private laboratories, ${ }^{126}$ and some are run by local governmental agencies such as the department of public safety or department of justice. ${ }^{127}$ Other states store DNA samples in a different department that is not directly affiliated with law enforcement. For

\footnotetext{
117 HaW. Rev. Stat. § 844d-31 (West 2006).

118 Cal. Penal Code $\S 296.1$ (2004); Haw. Rev. Stat. § 844d-31; Idaho Code § 19-5506 (2014); La. Stat. AnN. 15:609 (2010); Mo. Rev. Stat. § 650.055 (2012); Ohio Rev. Code AnN. 2901.07 (West 2012); S.D. Codified LaWs § 23-5A-1 (2016).

119 DEL CARMEN, supra note 85, at 56.

${ }^{120}$ Ark. Code Ann.§ 12-12-1109 (2003); HaW. Rev. Stat. § 844d-31.

${ }^{121}$ ALA. CODE $\S 36-18-24$ (2016).

12212 R.I. GEN. LAWS $\S 12-1.5-8$ (2015).

123 IND. CODE ANN. § 10-13-6-10 (West 2006).

124 Id.

125 Ala. Code § 36-18-25 (2016); Ariz. Rev. Stat. § 13-610 (LexisNexis 2016); Iowa Code § 81.2 (2014); Md. Pub. Safety Code Ann. § 2-504 (West 2009); Neb. Rev. Stat. § 29-4106 (2012); N.H. Rev. Stat. AnN. 651-C:2 (2010); N.Y. EXEC. LAW § 995-c (Consol. 2012); N.C. Gen. StAT. § 15A-266.4 (2011); 44 PA. Con. Stat. §2316 (2005); 12 R.I. Gen. Laws §12-1.5-8; Tenn. Code AnN. § 40-35-321 (2012); Wis. Stat. § 973.047 (2015); Cal. Penal Code § 296.1 (2004); VT. StAT. AnN. tit. 20 § 1933 (2016).

126 Md. Pub. Safety Code Ann.§ 2-504; N.M. Stat. Ann. § 29-6-13; N.D. Cent. Code § 31-13-03 (2011); W. VA. CODE § 15-2B-6 (2011); WIS. STAT. § 973.047.

127 Alaska Stat. § 44.41.035 (West 2010); ARIz. Rev. Stat. § 13-610; Ind. Code AnN. § 10-13-6-10; Miss. Code AnN. § 47-5-183 (2003); OHIO ReV. Code ANN. § 137.076.
} 
example, Rhode Island stores DNA samples in the Department of the Health. ${ }^{128}$ Texas analyzes DNA samples in any laboratory approved by the director. ${ }^{129}$

Some states (eleven out of fifty) have statutes discussing whether DNA profiles on the state level will automatically be submitted and compared to profiles in CODIS. Some statutes mention CODIS; however, the statutes do not specify whether a DNA profile will automatically be entered into CODIS. It has been suggested that it is ideal for DNA profiles to be entered into a national database to expand the scope of searching for a suspect's DNA. For example, Delaware requires its DNA database system to be "compatible with the procedures set forth in a national DNA identification index to ensure data exchange on a national level." ${ }^{130}$ Similar to fingerprint identification technology, DNA identification technology relies on a large database to make it meaningful when running comparisons, and CODIS satisfies this need. However, DNA is expensive to analyze, ${ }^{131}$ thus many states need federal funding to build a DNA database. ${ }^{132}$

\section{Other Provisions Worth Noting in Post-Conviction DNA Collection Laws}

Two features are worth noting in the post-conviction DNA collection statutes. First, only a few states have a section on expunging a DNA sample and DNA profile in the database. Although expunging a DNA sample and DNA profile is common in pre-conviction DNA collection statutes, it is difficult to find expungement processes in the post-conviction DNA collection statutes. So far, only Arizona's statute clearly describes an expungement process if a person's appeal or postconviction relief succeeds. ${ }^{133}$

Second, some states have provisions on when and how these DNA samples can be used. Since every physical characteristic of a person can be derived from DNA, the release and usage of DNA requires caution. Alabama's DNA collection statute states that DNA samples and profiles can only be released for three purposes: (1) law enforcement identification, ${ }^{134}$ (2) criminal defense and appeal, ${ }^{135}$ and (3) forensic validation studies. ${ }^{136}$ If researchers want to use DNA samples and profiles, the statute states that personal identification information must be removed. ${ }^{137}$ Michigan's statute allows DNA samples to be analyzed for research purposes. ${ }^{138}$ However, in Delaware and Florida, DNA collection statutes indicate that DNA profiles and DNA samples can only be used for law enforcement purposes. ${ }^{139}$

128 R.I. GEN. LAWS § 12-1.5-8 (2015).

129 TEX. Gov'T CODE ANN. § 411.1471 (2015).

${ }^{130}$ Del. Code AnN. tit. $29 \S 4713$ (2016).

${ }^{131}$ Athens \& Rower, supra note 49 , at 390.

132 Id. at 391.

${ }^{133}$ ARIZ. ReV. StAT. § 13-610 (LexisNexis 2016).

${ }^{134}$ ALA. CODE $§ 36-18-25$ (2016).

135 Id.

$136 / d$.

$137 / d$.

138 Mich. COMP. LAWS SERV. § 750.520m (LexisNexis 2015).

139 Del. Code Ann. tit. 29 § 4713 (2016); Fla. Stat. § 943.325 (2016). 


\section{Proposed Model Statutes}

Some states have merged pre- and post- conviction DNA collection laws together into one statute; ${ }^{140}$ while other states have different statutes with some overlaps. ${ }^{141}$ It is best to have separate statutes for pre- and post- conviction DNA collections because arrestees must be guaranteed their presumption of innocence. DNA contains significant genetic information that justifies the need for caution in collecting, storing, and analyzing such information; therefore, balancing crime control and due process in the DNA collection statutes is imperative. Below are suggestions towards model statutes based on the gaps that were identified under the current statutes for both pre- and post-conviction DNA laws.

\section{A. Model Statute for Pre-Conviction DNA Collection}

Appendix A contains the proposed model statute for pre-conviction DNA collection. Preconviction DNA statutes emphasize the due process model over crime control because arrestees benefit from the presumption of innocence until adjudicated guilty. The pre-conviction DNA statutes must contain the following basic contents: First, the crime type that needs a DNA sample from an arrestee should be clear in the statute. Compared to post-conviction DNA collection laws, the scope of crime type in pre-conviction DNA collection laws needs to be narrowed down to improve efficiency and ensure some degree of privacy to balance the crime control and due process models. For example, only suspects arrested for serious crimes (e.g., violent crimes and sex crimes) should be required to provide a DNA sample immediately after arrest. Those arrested for minor crimes should have the option to provide a DNA sample voluntarily. This also removes system overload and unnecessary expenses in local crime laboratories.

There must be a clear procedure in the statute for when law enforcement officers are authorized to collect DNA sample from an arrestee to ensure the fundamental fairness. Obtaining a search warrant is the best practice. For warrantless arrest cases, probable cause must be established and approved by a magistrate. Collecting DNA is not time sensitive. For example, blood alcohol level in drunk driving cases is time sensitive because such information dissipates after several hours, while DNA will remain the same. There is always enough time to obtain a search warrant or detect probable cause.

Each state must differentiate between adults and juveniles and if DNA should be collected. Juveniles who have been taken into custody should not be required to submit DNA. Also, the statute must indicate where DNA samples go and when they are used for analysis, as was the issue in King. ${ }^{142}$ To balance crime control and due process models, DNA samples collected from arrestees must be stored and analyzed in local crime laboratories to make it easier to opt for an expungement because once DNA samples and profiles go to a federal DNA database, it becomes harder to expunge them. The statute must have sections that explain the purpose for collecting DNA sample from arrestees. It must be clear that the only purpose for collecting DNA is identification-linking the arrestee to the crime in the present case, rather than unsolved cases.

\footnotetext{
140 E.g., Alaska Stat. § 44.41 .035 (West 2010); Colo. Rev. Stat. §16-23-103 (2010); Fla. Stat. § 943.325; 730 Ill. Comp. Stat. Ann. 5/5-4-3 (West 2014); Kan. Stat. AnN. § 21-2511 (2014); La. Stat. AnN. § 15:609 (2010); Mo. REV. STAT. § 650.055 (2012).

${ }^{141}$ E.g., ARK. Code ANn.§ 12-12-1006, 1105, 1109; N.J. StAT. § 53:1-20.20, 20.25 (2013).

142 Maryland v. King, 133 S. Ct. 1958 (2013).
} 
This is to prevent suspicion-less searches, which are forbidden by the Fourth Amendment. ${ }^{143}$ Moreover, the statute must contain provisions on the procedure for expungement if the arrestee has been found not guilty or the case is dismissed.

\section{B. Model Statute for Post-Conviction DNA Collection}

A model statute for post-conviction DNA law proposes standardization among the state statutes. This can be found in Appendix B. The post-conviction DNA collection statute emphasizes crime control model over due process. It must include the following basic contents: First, crime types that need a DNA sample from an arrestee should be well defined. Since DNA testing is expensive, ${ }^{144}$ there is no need for minor crime offenders to provide a DNA sample such as those convicted of theft under a specified amount. Second, every statute must indicate whether the law applies retroactively and identify a starting date. This allowed for better tracking of high-profile offenders. Also, the statute must be clear on whether DNA collection also applies to these who plead guilty, go on probation or parole, or other forms of release. Unlike pre-conviction DNA collection laws, post-conviction DNA collection laws should rule that juveniles must only provide DNA samples after they are adjudicated of serious crimes.

However, emphasizing the crime control model does not mean the due process model should be ignored. The statute must indicate where DNA samples will be stored, who can access it, and for what purpose to minimize possible abuse of DNA profiles and samples. Although the public does not have access to the DNA database, individuals who have such access should be known to the public. For example, law enforcement, the judiciary, and institutional research may need access to the DNA database. Giving the public such information will reduce the risk of the information being misused.

In addition, similar to the proposed pre-conviction DNA statute, the post-conviction DNA statute should also contain detailed information on the expungement process of DNA samples and profiles. Based on the crime control model, convicted offenders must provide DNA samples incident to future recidivism. However, although these offenders have been convicted, they have the right to appeal. If the appeal succeeds, the DNA information must be expunged to fulfill goals of the due process model. The government might be reluctant to erase DNA profiles and samples since DNA testing has become a powerful tool in exonerations in wrongful conviction cases. Postconviction DNA collection statutes need sections on destroying DNA profiles and samples in the DNA database. In addition, the statute should indicate whether state DNA profiles will go to the federal DNA database such as CODIS or if it will only be used to check for matches against the federal DNA database. There are three justifications: First, DNA profiles that are entered into the federal databases are harder to control. Second, if CODIS already has the DNA profile of an offender, the state will not need to run DNA analysis again. Third, it is better to limit how and when these DNA samples and profiles in the database can be used. Unlike identification before conviction, post-conviction DNA collection can be used to link the defendant to other unsolved crimes, which is a goal in the crime control model. To sum, a perfect balance between crime control and due process models in DNA collection is not possible; but these model statutes propose

${ }^{143} / d$.

${ }^{144}$ Athens \& Rower, supra note 49, at 390. 
evidence of a balance from both sides. Since DNA contains more private genetic information than fingerprints, more safeguards are needed to protect individual rights.

\section{Conclusion}

DNA collection understandably draws both respect and criticism. This study analyzed both pre- and post- conviction DNA collection laws, focusing on important variables that are in the current pre- and post- conviction DNA collection statutes. All fifty states have statutes on postconviction DNA collection whereas only thirty states have pre-conviction DNA collection statutes. Some statutes are specific and comprehensive, while others are brief and generic. This study suggests that each variable analyzed should be included and addressed in every state's pre- and post-conviction DNA collection statutes. It recommends that more safeguards be included in state statutes to limit pre-conviction DNA collection and analysis. For the states that do not have preconviction DNA collection statutes, it is recommended that the model statute be used to initiate state legislation.

The model statutes seek a balance between the crime control and due process models. ${ }^{145}$ The collection of such personal genetic information by the government must be protected to reduce abuse. DNA evidence is a powerful tool in the criminal justice system that can incarcerate the guilty, but also exonerate the innocent. It is a major and effective tool for law enforcement that a democratic society must use cautiously and wisely. DNA laws are crucial for all states to adopt to administer justice while maintaining individual privacy.

\section{Declaration of Conflicting Interests}

The author declares no potential conflicts of interest with respect to the research, authorship, and/or publication of this article.

\section{Funding}

The author received no financial support with respect to the research, authorship, and/or publication of this article.

\section{Appendix A: Proposed Model Statute for Pre-Conviction DNA Collection}

1. Any person who is 16-year-old or older arrested of a crime listed in section 2 on or after 90 days of the statute enacted must have DNA sample collected by law enforcement during the booking process. A search warrant and/or probable cause are needed to justify DNA collection.

2. Applicable offenses are listed as follows: ${ }^{146}$ murder in the first or second degree; felony murder; manslaughter; aggravated assault; attempted aggravated assault; gross sexual assault; rape; sexual abuse of a minor; unlawful sexual contact; sexual offenses against a child under 14 years of age; kidnapping; criminal restraint; burglary; arson; aggravated criminal mischief; or causing a catastrophe.

\footnotetext{
145 Packer, supra note 31.

${ }^{146}$ Based on crime types listed in 25 M.R.S. § 1574.
} 
3. Any person who is arrested for a crime not listed in section 2 can submit DNA with consent during booking process. The person has the right to refuse providing a DNA sample and this refusal cannot be used as evidence against the person.

4. All DNA samples and profiles must be stored in the local crime laboratories and analyzed for identification purpose only by law enforcement. Both DNA sample and profile collected and created during the booking process must not be submitted to statewide or federal databases such as the Federal Bureau of Investigation's Combined DNA Index System (CODIS) until the person is adjudicated guilty. DNA profiles in the local crime laboratories can be compared to profiles in the stateside and federal databases if necessary, but for identification purposes only.

5. If a person is found not guilty or the case is dismissed, both DNA sample and profile of the person in the local crime laboratory must be expunged immediately and a letter must be sent to the court verifying the expungement is completed.

\section{Appendix B: Proposed Model Statute for Post-Conviction DNA Collection}

1. A person convicted on or after 90 days of the statute enacted of a crime listed in section 2 shall submit a DNA sample at the time of adjudication of guilt. If a person convicted submitted DNA at arrest, he or she does not have to submit DNA at adjudication.

2. Applicable offenses are listed as follows: ${ }^{147}$ murder in the first or second degree; felony murder; manslaughter; aggravated assault; attempted aggravated assault; gross sexual assault; rape; sexual abuse of a minor; unlawful sexual contact; sexual offenses against a child under 14 years of age; kidnapping; criminal restraint; burglary; arson; aggravated criminal mischief; or causing a catastrophe.

3. A juvenile adjudicated delinquent of a crime on or after 90 days of the statute enacted listed in section 2 shall be taken a DNA sample.

4. All DNA samples of persons convicted must be stored and analyzed in statewide crime laboratories run by state government. DNA profiles of persons convicted are automatically submitted to the Federal Bureau of Investigation's Combined DNA Index System (CODIS) to allow exchange of DNA records submitted by federal, state, and local crime laboratories. DNA from adjudicated delinquents must only be stored and analyzed in statewide crime laboratories run by state government.

5. All DNA samples and profiles must only be disclosed to the following entities: $(A)$ to a law enforcement agency for identification purpose only; (B) in a judicial proceeding; (C) to a defendant or his or her attorney if the DNA sample is related to the defendant; or (D) for academic research. If DNA samples and profiles are used for academic research purposes, names must be removed. ${ }^{148}$

6. If the conviction or adjudication of a person is overturned on appeal or post-conviction relief, both DNA sample and profile must be expunged. ${ }^{149}$ A certified copy of the court order must show proof that conviction has been reversed. The DNA sample in the state crime laboratory must be destroyed. The DNA profiles in both state and federal DNA

147 Based on crime types listed in 25 M.R.S. § 1574.

${ }_{148}$ Based on Code of Ala. § 36-18-25.

149 Based on A.R.S. § 13-610. 
databases must be deleted. A certified copy of these expungement motions must be delivered to the court and the defendant.

\section{Authors' Biographies}

Xiaochen $\mathrm{Hu}$ is a faculty member in the Department Criminal Justice at Fayetteville State University. He obtained his B.S. in Applied Psychology from China, M.S. in Criminal Justice from the University of Cincinnati, and Ph.D. in Criminal Justice from Sam Houston State University.

Mai E. Naito is an Assistant Professor in the Department of Criminology at the University of West Georgia. She obtained her B.A. in Criminal Justice from the University of West Florida, M.A. in Criminology from the Indiana University of Pennsylvania, and Ph.D. in Criminal Justice from Sam Houston State University.

Rolando V. del Carmen is a Distinguished and Regents Professor in the College of Criminal Justice and Criminology at Sam Houston State University. He obtained B.A. and L.L.B. degrees from the Philippines, an M.C.L. from Southern Methodist University, and L.L.M. from the University of California-Berkeley, and a J.S.D. from the University of Illinois. He is the co-director of the Institute for Legal Studies in Criminal Justice at Sam Houston. 